\section{THE TRANSIT OF VENUS}

T'HE following telegrams have been received by the Times since our last issue.

"Melboume, Dec. II.-The American Expedition in Tasmania experienced unfavourable weather for their observations of the Transit of Venus."

"Syaney, Dec. 10.- The Transit observations here proved satisfactory."

"Berlin, Dec i 7.--A telegram has been received from the German Astronomical Expedition at Tschifu, in Northeastern China, announcing that the observation of the Transit of Venus was quite successful. The observation of the contact, the heliometer measurement, and the photographs succeeded splendidly. The expedition was admirably supported by His Imperial Majesty's ship Arcona."

From Major Palmer, Christchurch, New Zealand :-

"English, nothing valuable anywhere-clouds. Americans got ingress, and photographs till near third con. tact. Nobody egress."

From Mr. Todd, Adelaide:-

"Transit of Venus.-Ingress cloudy. Egress well observed. Contacts 34434,3475 . (Probably $3 \mathrm{~h}$. $4 \mathrm{~m}$. $43^{\circ} 45$, and $34 \mathrm{~m} .75^{\circ} \mathrm{s}$. Adelaide mean time, for internal and external contacts.) No black drop."

From Vienna :-

"According to a telegram received by the Imperial Academy of Sciences from Drs. Weiss and Oppolzer, who went to observe the Transit of Venus at Jassy, the observation of external contact at the moment of the exit has succeeded. As they had time to fix the exact longitude and latitude of their point of observation, they obtained reliable data for calculation. The longitude was determined by telegraphic time signals with the Observatory in Vienna. As Jassy lies on the limits of the line where the phenomenon was visible, they attribute some importance to their observations."

Through Reuter's agency: -

"Yclin, Dec. 9.-The French astronomical party, under the direction of M. Fleuriais, succeeded in observing the first and second contacts. There was a slight black ligament. Photographs were taken. The weather was slightly hazy."

It will be seen that the news from New Zealand is of a most serious character, so far as the English scheme of observation is concerned. In fact, unless the French, Germans, and Americans have secured observations, the Delislean attack, so far as egress is concerned, has failed altogether. We shall postpone any further remarks till next week, as in the interval some information may be received from the stations to which we have referred.

\section{NOTES}

WE are informed that the Council of the Royal Society has appointed a Committee to consider the means of securing observations of the total eclipse of the sun in April next, to which they attach great importance.

Prof. Clerk.Maxweli, F.R.S., has promised to give a lecture at the Chemical Society on Feb. I8 next, "On the Dynamical Evidence of the Molecular Constitution of Bodies."

THE. Times states that Prof. Huxley is to undertake the duties of the Chair of Natural History in the University of Edinburgh during the ensuing summer session, in the absence of Prof. Wyville Thomson, who is with the Challenger Surveying Expedition.

THE Arctic Expedition Committee sits twice a week, and is making steady progress in organising preparations. The engines of the Cygnet gunboat, a new vessel, are to be removed and placed in the Alert, now in dock. Although not yet officially announced, we believe that the Admiralty have selected Commander Albert Markham as one of the commanding officers of the Arctic Expedition. Lieut. Aldrich, of the Challenser, is coming home with Capt. Nares to take part in the expedition. The decision recently made public that none but those of the Royal Navy would be permitted to take part in the expedition has been somewhat relaxed, and it is not improbable that some men of experience in whaling will be engaged as "ice quartermasters."

WE believe a few French naval officers desire to join the forthcoming English Polar Expedition, as Lieut. Bellot did on the occasion of one of the most interesting searches for Franklin. As is known, Bellot lost his life during the expedition, and the fact is commemorated by a column erected at Greenwich Hospital at the expense of the English Government.

Lievt. Cameron, in a despatch to Lord Derby, cated Ujiji, May 14, tells of an important discovery to which we briely alluded last wetk in our report of the meeting of the Cengraphical Society:: He has been all round the southern portion of Tanganyika, and believes he has discovered its outlet in a river named the Lukuga, a little to the south of Speke's Islands. He thinks also, from what he has heard from the Arabs, that the Lualaba is the Congo. The Lukuga he found to be obstructed with grass, but he believes a way might easily be cut through that. If Lieut. Cameron's conjectures turn out to be correct, and there appears to be great likelihood that they will, he will deserve to take an important place in the ranks of African explorers. He shows the great capabilities of Central Africa as a field for legitimate commerce, and if it turns out that navigation is possille from the mouth of the Congo to the Tanganyika region, much good may be expected to accrue to Africa as well as to the commercial world at large. The curse of the country is still those degraded Arab slave-dealers who vexed the soul of poor Livingstone, and it is a monstrous pity that some steps could not be taken to stamp out the demoralising and devastating traffic. If ull details of Lieut. Cameron's explorations are in the hands of the Geographical Society.

The last two parts of Petermann's Millikitung an are naturally full of the Payer-Weyprecht expedition. The Decenber number contains two letters from Lieut. Weyprecht, and one from Lieut. Payer, to Dr. Petermann. The former intimates that the amount of material collected in connection with the Eeography, meteor. ology, magnetism, \&c., is immense; during the course of next year he will be preparing these for publication. He briefly states, as some of the conclusions he draws from the work of tire expedition, that it is erroneous to conclude either that an open polar sea exists in the north, or that the ice on the south of Franz-Joseph's Land is impenetrable; that the drift of the ship in the ice was in no way owing to the Gulf Stream ; and that he still adheres to the opinion that much valuable exploratory work can be done towards the east, with the Siberian const as a basis of operations. Lieut. Payer believes that the nearest road to the pole is that by which the English Arctic Expedition is to goSmith's Sound.

THE Daily' Telesraph of Monday contains a long letter siving a very interesting account of Zanzibar, from Mr. H. M. Stanley, the leader of the expedition sent out by that paper in conjunction with the Now York Howald. Another is to follow giving a description of the preparations for Stanley's long Africau march of discovery, and the detailed plans of route. This expedition is exceedingly creditable to the two papers, and it is a hopefu 1 sign that a daily journal finds it answer to fill its columns with such healthy excitement.

A CoMmUNiCATION from her Majesty's ship Scout states that a monument has been erected on one of the isiands of the Pacific to the memory of Captain Cook, who was killed by the natives of Owhylee, ninety-five years ago. The monument is an 